\title{
Effect of Gaillardin on Proliferation and Apoptosis of Acute Promyelocytic Leukemia Cell Lines, NB4 as Cancer Treatment
}

\author{
Mohammad Sayyadi ${ }^{1}$, Alireza Moradabadi ${ }^{2}$, Ali Noroozi-Aghideh ${ }^{1, *} \mathbb{D}$, Mohsen Yazdanian ${ }^{3}$ \\ Department of Hematology, Faculty of Paramedicine, Aja University of Medical Sciences, Tehran, Iran \\ Department of Hematology, Amir-Kabir Hospital, Arak University of Medical Sciences, Arak, Iran \\ Research Center for Prevention of Oral and Dental Diseases, Baqiyatallah University of Medical Sciences, Tehran, Iran \\ Correspondence: a.noroozi@ajaums.ac.ir
}

Scopus Author ID 36700140500

Received: 22.05.2020; Revised: 13.06.2020; Accepted: 15.06.2020; Published: 17.06.2020

\begin{abstract}
Acute promyelocytic leukemia is the most prevalent AML malignancy. The side effects caused by chemotherapeutic drugs have primarily led to the increased use of natural products for cancer treatment. Gaillardin, a medicinal herb, has been reported to have anti-proliferative effects on various cancer cells. In this study, cytotoxic and apoptotic effects of Gaillardin were investigated on acute promyelocytic leukemia cell lines, NB4. Different concentrations of Gaillardin were used to treat NB4 cells for 48 and 72 hours. Then cell viability was assessed using MTT assay. Flow cytometry was applied to the assessment of apoptosis by using Annexin V and Propidium iodide staining method. In order to determine the expression levels of Bax and Bcl-2, RT-PCR was carried out. Statistical data analysis was done by ANOVA (one-way). MTT assay results showed that Gaillardin concentrations of 7,8 , and $9 \mu \mathrm{M}$ would significantly reduce the percentage of live cells $(\mathrm{P}<0.001)$ c. Flow cytometry results showed that Gaillardin significantly increased apoptotic cell percentage in comparison with the control groups $(\mathrm{p}<0.05)$. Gaillardin can be considered as a candidate for further studies on the methods for treating various cancer types.
\end{abstract}

Keywords: Gaillardin; Cytotoxicity; Apoptosis; Leukemia.

(C) 2020 by the authors. This article is an open-access article distributed under the terms and conditions of the Creative Commons Attribution (CC BY) license (https://creativecommons.org/licenses/by/4.0/).

\section{Introduction}

Acute Myeloid Leukemia (AML) consists of very different disorders of neoplastic type with significantly various clinical courses and responses to therapy with different pathological bases in both genetic and molecular terms [1-3]. APL, as an acute myeloid leukemia subclass, emanates from a translocation of chromosomes, creating the PML/retinoic acid (RA) receptor $\alpha$ [4-6] fusion protein. This protein influences the signaling of the nuclear receptor and PML body assembly $[7,8]$.

Its unique morphology and the mutual translocation of chromosomes 15 and 17 are the distinguishing characteristics of the disease. APL has traditionally been identified by a course of quick fatality and high rates of early death due to hemorrhage. In the initial research studies on the disease, the median survival of the untreated patients and those treated by corticosteroids was reported to be less than a week within the range of a day to a month. The dramatic advancements in achieving effective treatments for APL have increased overall cure rate to higher than $80 \%$, providing the grounds for developing novel herbal strategies to increase the 
efficacy of treatments, on the one hand, and decrease the toxic side-effects of the existing intensive regimens, on the other hand $[4,9,10]$. Medicinal herbs with natural origins are more compatible than chemical drugs with living organisms and cause fewer side effects. Thus, they have drawn considerable attention as a potential resource of new supplements for chemotherapy drugs. Extracts of various medicinal plants have accordingly received extensive applicability to cancer treatment [11-14]. Sesquiterpene lactones as a class of secondary metabolites are an instance of such extracts, which are taken from Asteraceae. However, other families, e.g., the Cactaceae, Solanaceae, and Euphorbiaceae, may contain the sesquiterpenoids [15]. Many traditional medicinal plants used to cure various diseases like infections, inflammation, and headache comprise Sesquiterpene lactones (SLs) as an active constituent. An instance of the natural sesquiterpene lactone is Gaillardin, for which anticancer features have been reported in some recent studies $[16,17]$. The present research intended to explore the therapeutic effects of Gaillardin extract on the APL cell line (NB4).

\section{Materials and Methods}

\subsection{Extraction.}

Inula oculus-Christi air-dried powder ( $250 \mathrm{~g})$ was macerated with $\mathrm{n}$-hexane $(2500 \mathrm{~mL})$ at RT for $24 \mathrm{~h}$ and continuously shaken. After filtering the mixture, the residue was again macerated with fresh solvent (thrice). After three days, using chloroform $(2500 \mathrm{~mL})$, the residue of the plant material was extracted. This was repeated in the following three days, again. The accumulated extract of chloroform was employed to isolate Gaillardin [16, 18-20].

\subsection{Cell culture and Gaillardin extract treatment.}

The authors asked Pasteur Institute of Iran to supply NB4 (acute promyelocytic leukemia cell lines) and MDBK cells (Bovine kidney cell line). These cells were cultured in RPMI 1640 medium complemented with $2 \mathrm{mM}$ L-glutamine, 10\% FBS, 100 units $/ \mathrm{ml}$ penicillin, and $100 \mu \mathrm{g} / \mathrm{ml}$ streptomycin in a humidified 5\% CO2 incubator at a temperature of $37{ }^{\circ} \mathrm{C}$ in standard cell culture conditions. Gaillardin stock solution of relevant amounts was utilized in treating the cells in order to attain a concentration of .01-20 $\mu \mathrm{M}$.

\subsection{Trypan blue exclusion assay.}

For investigating the Gaillardin effects on viability and logarithmic growth of the cells, they were seeded at $1 \times 105$ cells $/ \mathrm{mL}$ and incubated with Gaillardin at different indicated concentrations for $72 \mathrm{~h}$. Then, the suspension of cells was mixed with a blue solution of $0.4 \%$ try-pan at the ratio of 1:1. The mixture was incubated for 1-2min at room temperature, and then, it was discharged into the chamber of Neubauer hemocytometer. In the end, the following formula was adopted to calculate the cell viability index:

$$
\text { Viability }(\%)=\text { viable cell count/total cell count } \times 100 \text {. }
$$

\subsection{MTT assay.}

Cytotoxicity was evaluated through MTT assay. The suspension cells (NB4) were briefly cultured at 5000/well in a 96-well plate and incubated with desired concentrations of Gaillardin for 48 and $72 \mathrm{~h}$. The media were removed, and MTT solution ( $5 \mathrm{mg} / \mathrm{ml}$ in PBS) was 
used further to incubate the cells at $37^{\circ} \mathrm{C}$ for $3 \mathrm{~h}$. A bunch of cells remained untreated as the control group. Dimethyl sulfoxide (DMSO) was utilized to solubilize the achieved formazan. Absorption was estimated at $570 \mathrm{~nm}(620 \mathrm{~nm}$ as reference) in ELISA reader, and IC50 was calculated as the concentration of fractions and compounds, causing $50 \%$ inhibition of cell viability $[21,22]$.

\subsection{Phosphatidylserine externalization (Annexin-V/PI assay).}

Annexin-V/PI double staining kit (eBioscience) was employed following the instructions of the manufacturer to analyze the apoptosis caused by Gaillardin. In summary, leukemic cells were cultured in 12-well plates and treated at different concentrations of Gaillardin for $48 \mathrm{~h}$; then, they were collected. Afterward, $200 \mu \mathrm{l}$ binding buffer and then, $5 \mu \mathrm{l}$ Annexin-V were added to the suspension of cells and incubated for $10 \mathrm{~m}$. The following step was rinsing the cells and adding $200 \mu \mathrm{l}$ binding buffer. After adding PI, the values were read with flow cytometry. It was supposed that PI-negative and Annexin-V positive cells were in the beginning stage of apoptosis, and cells with Annexin-V and PI-positive underwent late apoptosis or necrosis.

\subsection{RNA purification, reverse transcription, and real-time PCR amplification.}

Forty-eight hours after utilizing RNX plus (SinaClon, Iran) to make the treatment with Gaillardin, total RNA was isolated. By applying Strand cDNA Synthesis Kit (Takara BIO), Reverse Transcription (RT) reaction was carried out. The achieved cDNA was exposed to qRTPCR on a light cycler instrument (Roche). Thermal cycling comprised the following conditions, the activation step for $30 \mathrm{~s}$ at $95^{\circ} \mathrm{C}$ in 45 cycles, which consisted of a denaturation step for $5 \mathrm{~s}$ at $95^{\circ} \mathrm{C}$ and a combined annealing/extension step for $20 \mathrm{~s}$ at $60^{\circ} \mathrm{C}$ [23-27]. , The specificity of the products was evaluated by melting curve analysis, and, through the formula of $2-\Delta \Delta \mathrm{Ct}$ for relative expression, the relative quantification values were determined. Table 1 presents the nucleotide sequences of the primers utilized for qRT-PCR.

Table 1. Nucleotide sequences of primers used in real-time RT-PCR.

\begin{tabular}{l|l|l|l|l} 
Gene & Accession number & Forward primer $\left(\mathbf{5}^{\prime} \mathbf{-} \mathbf{3}^{\prime}\right)$ & Reverse primer $\left(\mathbf{5}^{\prime} \mathbf{- 3}^{\prime} \mathbf{)}\right.$ & Size \\
\hline ABL & NM_005157 & TCCTCGTCCTCCAGCTGTTA & TCCTCGTCCTCCAGCTGTTA & $\mathbf{2 1 8}$ \\
\hline Bad & NM_004322 & CCCAGAGTTTGAGCCGAGTG & CCCATCCCTTCGTCGTCCT & $\mathbf{1 4 9}$ \\
\hline Bax & NM_138761 & CGAGAGGTCTTTTTCCGAGG & GTGGGCGTCCCAAAGTAGG & $\mathbf{2 4 2}$ \\
\hline Bcl-2 & NM_000633 & CGGTGGGGTCATGTGTGTG & CGGTTCAGGTACTCAGTCATCC & $\mathbf{9 0}$
\end{tabular}

2.7. Statistical analysis.

Mean \pm standard deviation for each independent assay was used to account for the experimental data. All tests were performed two or three times. To compute statistical significance, Student's t-tests of paired two-tail type were applied. $* \mathrm{P}<0.05$, ** $\mathrm{P}<0.01$, and $* * * \mathrm{P}<0.001$ were considered for the significance of various statistical values.

\section{Results and Discussion}

\subsection{Reduction in NB4 cell viability by Gaillardin.}

To find out if Gaillardin could decrease the APL-derived leukemic cell survival rate, various concentrations of this natural agent (1-20 $\mu \mathrm{M})$ were treated in NB4. Then, after $48 \mathrm{~h}$, 
to undergo trypan blue assays, the cells were collected. Figure 1 indicates that Gaillardin dosedependently reduced the number of viable cells.
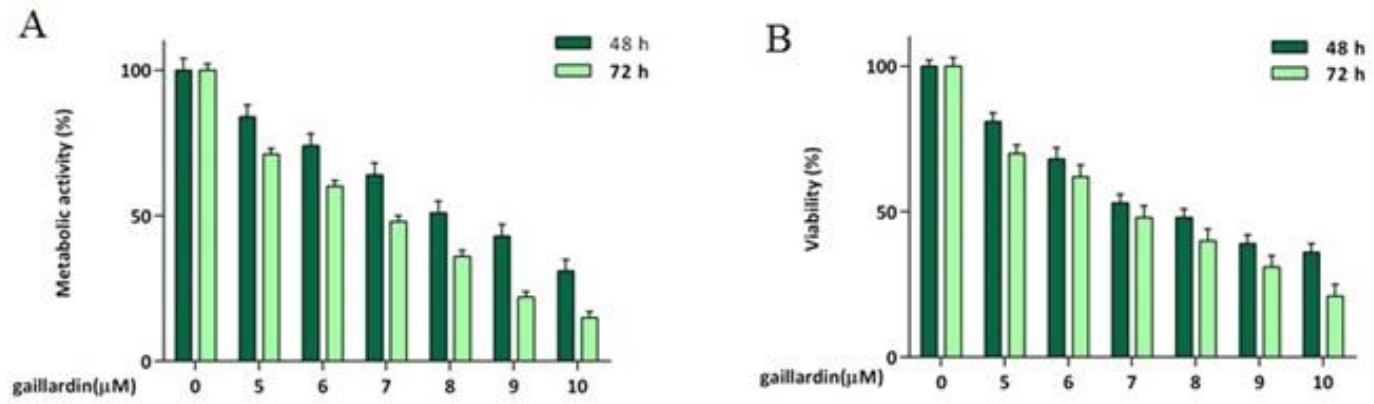

Figure 1. Effect of Gaillardin on the proliferation of potential and metabolic activity of NB4 cells. A: The inhibitory effect of Gaillardin on NB4 cell metabolic characteristics was specified through trypan blue and MTT assay. B: Cells were seeded in a 96-well plate at a density of 5000 cells/well and treated with the suggested Gaillardin concentrations.

\subsection{Reduction in cellular metabolic activity of NB4 cells by Gaillardin.}

The cytotoxic effects of different concentrations of Gaillardin (1-20 $\mu \mathrm{M})$ on NB4 cells' metabolic activity after treatment for 48 and $72 \mathrm{~h}$ were evaluated through MTT assay. Figure 1 demonstrates that the extract of Gaillardin would dose- and time-dependently reduce the NB4 cells' survival. The IC50 value of Gaillardin extract in NB4 cells after incubation for $48 \mathrm{~h}$ was approximately $7 \mu \mathrm{M}$. In addition, MDBK cells were used as the normal cell line to examine the effect of this extract on normal cells. The IC50 value of Gaillardin for MDBK cells was approximately $20 \mu \mathrm{M}$ after incubation for $48 \mathrm{~h}$, suggesting the lower cytotoxic effect of this extract on MDBK cells than on acute promyelocytic leukemia cell line (Figure 2).
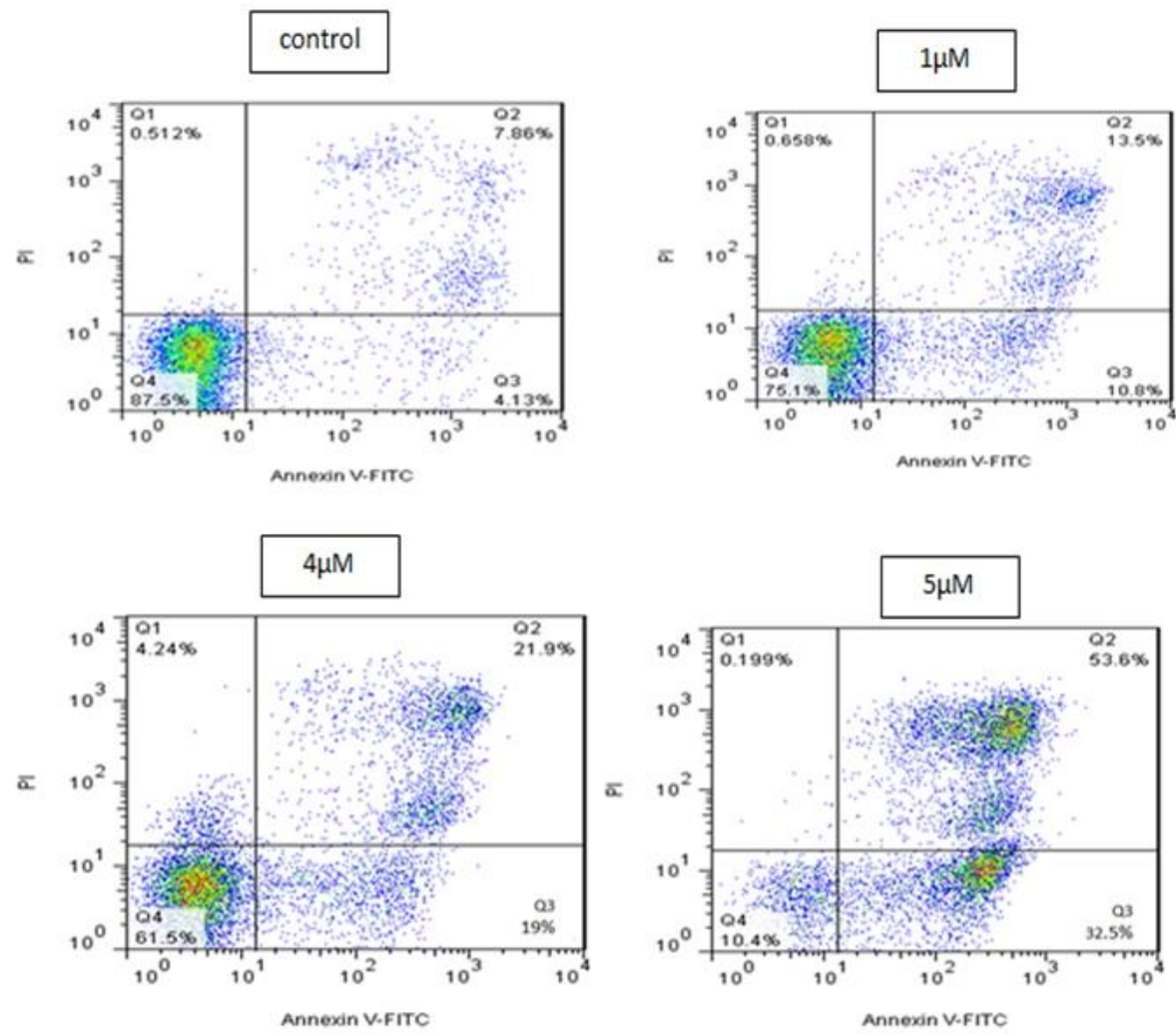

Figure 2. Increase in Annexin-V/PI double-positive treated cells percentage after Gaillardin treatment of NB4 cell lines in comparison to the untreated group. 


\subsection{Apoptosis induction in APL cell lines by Gaillardin extract.}

To validate whether cell survival reduction was due to apoptosis induction, varying Gaillardin concentrations were used to treat NB4 cells. The apoptosis index was examined through Annexin-V/PI assay after $48 \mathrm{~h}$ incubation through the flow cytometry technique. Results showed that Gaillardin was capable of dose-dependently inducing apoptosis in the APL cell line. One, 4, and $5 \mu \mathrm{M}$ doses of Gaillaredin extract caused 10.5, 19, and 32\% early apoptosis in NB4 cells, as shown in Figure 2.

\subsection{Increased transcription of Bax and reduced transcription of Bcl-2 in APL cell lines by} Gaillardin.

Bax (pro-apoptotic) and Bcl-2 (anti-apoptotic) are the most important protein members of the Bcl-2 family. They have a central role in regulating programmed cell death (apoptosis). Accordingly, the expression of Bax and Bcl-2 genes was quantified after treating cells with the suggested concentrations of the extract after $48 \mathrm{~h}$ of incubation to delve into the influence of Gaillardin extract on apoptosis induction in NB4 cells. The regulation of gene expression was expressed as fold differences between control and treatment groups, as shown in Figure 3. Results indicated a rise in the transcription of Bax and a reduction in transcription of Bcl-2 as compared to the control. Reduction in Bcl-2 mRNA level besides an up-regulated transcription of Bax caused an increase in the transcriptional ratio of Bax/Bcl-2 after NB4 cells treatment with Gaillardin extract. The mentioned increase and decrease disturbed the balance of pro- and anti-apoptotic proteins against anti-apoptotic factors in APL cell lines.

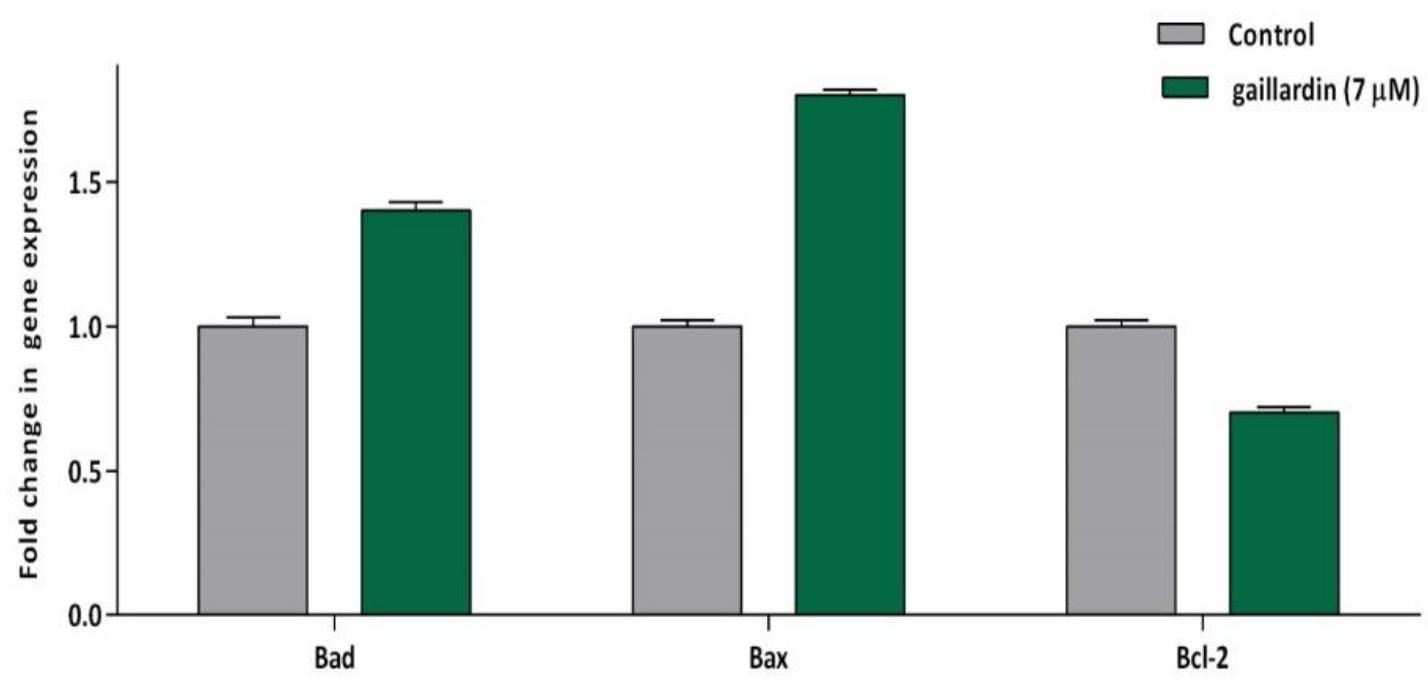

Figure 3. Effect of Gaillardin on transcriptional levels of Bad, Bax, and Bcl-2. Indicated Gaillardin concentrations were used to treat NB4 cells for $48 \mathrm{~h}$. After extracting RNA and synthesizing cDNA, real-time RT-PCR was employed to measure the relative mRNA expression of each gene in inhibitor-treated cells following the normalization of the cycle thresholds $(\mathrm{Ct})$ of each triplicate against its corresponding $\mathrm{ABL}$.

Plants are considered as a preliminary source of fairly efficient drugs in curing many diseases [28]. Nowadays, many clinically approved or under-trial anticancer medications are being derived from nature. Sesquiterpene lactones constitute a major group of secondary plant metabolites triggering numerous biological activities associated with considerable reactivity of their $\alpha$-methylene- $\gamma$-lactone groups through Michael-type reactions [27, 29-32]. 
In this study, we observed that Gaillardin would induce a considerable dose- and timedependent cytotoxic effect on the acute promyelocytic leukemia cell lines, namely NB4. Our results showed that Gaillardin caused death in APL cell lines (NB4) through apoptosis induction, which increased dose-dependently. Fallahian et al. showed that Gaillardin would trigger apoptosis in MCF-7 and MDA-MB-468 (breast cancer) cell lines 11 [16].

Apoptosis is a highly regulated and conserved cellular process controlled by regulators. These regulators either prevent programmed cell death (anti-apoptotic) or hinder the shielding effect of inhibitors (pro-apoptotic). Among the intracellular factors, the Bax (powerful apoptosis activator) and Bcl-2 (anti-apoptotic counterpart of Bax) balance are known as the most significant parameter in cell survival [33]. Therefore, the mRNA expression levels of Bax and Bcl-2 were investigated to evaluate the impact of Gaillardin on cell death induction. Our gene expression study demonstrated that Gaillardin would increase Bax and decrease Bcl-2 expression in APL cell lines. These findings indicate the disruption of the balance of pro- and anti-apoptotic proteins in favor of pro-apoptotic proteins, which finally leads to the induction of apoptosis. In general, it can be concluded that Gaillardin prevents Bcl-2 and dimerizes Bax, which initiate releasing cytochrome $\mathrm{c}$ from the mitochondria and activating caspase- 3 . This phenomenon, in the final run, induces cell death.

In summary, our study demonstrated that Gaillardin could induce apoptosis in APL cell lines. However, further investigations, including clinical trials and a detailed survey of the underlying Gaillardin mechanism of action, were pursued to establish the effectiveness of this natural agent $[34,35]$. The present study showed that Gaillardin had anti-leukemic properties, and the mechanism of action was likely to be dependent on transcriptional regulation of apoptotic signaling proteins.

\section{Conclusions}

The present findings provide evidence of the anti-leukemic activity of Gaillardin and suggest the consideration of this agent as a promising source of developing novel therapeutics against acute promyelocytic leukemia. Further understanding of the exact mechanism (s) of the anti-leukemic effects of Gaillardin is intriguing. It will hopefully result in new ways in treatment not only of leukemia but also in other malignant diseases.

\section{Funding}

This research received no external funding.

\section{Acknowledgments}

The authors are deeply thankful to all colleagues of the Tasnim Biotechnology Research Center at Aja University of Medical Sciences for their kind help.

\section{Conflicts of Interest}

The authors declare no conflict of interest.

\section{References}

1. Döhner, H.; Weisdorf, D.J.; Bloomfield, C.D. Acute myeloid leukemia. New England Journal of Medicine 2015, 373, 1136-1152. 
2. Skayneh, H.; Jishi, B.; Hleihel, R.; Hamieh, M.; Darwiche, N.; Bazarbachi, A.; El Sabban, M.; El Hajj, H. A Critical Review of Animal Models Used in Acute Myeloid Leukemia Pathophysiology. Genes (Basel) 2019, 10, https://doi.org/10.3390/genes10080614.

3. Castro, I.; Sampaio-Marques, B.; Ludovico, P. Targeting Metabolic Reprogramming in Acute Myeloid Leukemia. Cells 2019, 8, https://doi.org/10.3390/cells8090967.

4. Platzbecker, U.; Avvisati, G.; Cicconi, L.; Thiede, C.; Paoloni, F.; Vignetti, M.; Ferrara, F.; Divona, M.; Albano, F.; Efficace, F.; Fazi, P.; Sborgia, M.; Di Bona, E.; Breccia, M.; Borlenghi, E.; Cairoli, R.; Rambaldi, A.; Melillo, L.; La Nasa, G.; Fiedler, W.; Brossart, P.; Hertenstein, B.; Salih, H.R.; Wattad, M.; Lubbert, M.; Brandts, C.H.; Hanel, M.; Rollig, C.; Schmitz, N.; Link, H.; Frairia, C.; Pogliani, E.M.; Fozza, C.; D'Arco, A.M.; Di Renzo, N.; Cortelezzi, A.; Fabbiano, F.; Dohner, K.; Ganser, A.; Dohner, H.; Amadori, S.; Mandelli, F.; Ehninger, G.; Schlenk, R.F.; Lo-Coco, F. Improved Outcomes With Retinoic Acid and Arsenic Trioxide Compared With Retinoic Acid and Chemotherapy in Non-High-Risk Acute Promyelocytic Leukemia: Final Results of the Randomized Italian-German APL0406 Trial. J Clin Oncol 2017, 35, 605612, https://doi.org/10.1200/JCO.2016.67.1982.

5. Gambacorta, V.; Gnani, D.; Vago, L.; Di Micco, R. Epigenetic Therapies for Acute Myeloid Leukemia and Their Immune-Related Effects. Front Cell Dev Biol 2019, 7, https://doi.org/10.3389/fcell.2019.00207.

6. Winer, E.S.; Stone, R.M. Novel therapy in Acute myeloid leukemia (AML): moving toward targeted approaches. Ther Adv Hematol 2019, 10, https://doi.org/10.1177/2040620719860645.

7. Arber, D.A.; Orazi, A.; Hasserjian, R.; Thiele, J.; Borowitz, M.J.; Le Beau, M.M.; Bloomfield, C.D.; Cazzola, M.; Vardiman, J.W. The 2016 revision to the World Health Organization classification of myeloid neoplasms and acute leukemia. Blood 2016, 127, 2391-405, https://doi.org/10.1182/blood-2016-03-643544.

8. Lindsley, R.C.; Mar, B.G.; Mazzola, E.; Grauman, P.V.; Shareef, S.; Allen, S.L.; Pigneux, A.; Wetzler, M.; Stuart, R.K.; Erba, H.P. Acute myeloid leukemia ontogeny is defined by distinct somatic mutations. Blood 2015, 125, 1367-1376, https://doi.org/10.1182/blood-2014-11-610543.

9. de Thé, H.; Pandolfi, P.P.; Chen, Z. Acute promyelocytic leukemia: a paradigm for oncoprotein-targeted cure. Cancer cell 2017, 32, 552-560, https://doi.org/10.1016/j.ccell.2017.10.002.

10. Stuani, L.; Sabatier, M.; Sarry, J.E. Exploiting metabolic vulnerabilities for personalized therapy in acute myeloid leukemia. BMC Biol 2019, 17, https://doi.org/10.1186/s12915-019-0670-4.

11. Lo-Coco, F.; Di Donato, L.; Schlenk, R.F. Targeted Therapy Alone for Acute Promyelocytic Leukemia. $N$ Engl J Med 2016, 374, 1197-8, https://doi.org/10.1056/NEJMc1513710.

12. Tahmasebi, E.; Alikhani, M.; Yazdanian, A.; Yazdanian, M.; Tebyanian, H.; Seifalian, A. The current markers of cancer stem cell in oral cancers. Life Sci 2020, 249, 117483, https://doi.org/10.1016/j.lfs.2020.117483.

13. Ram, G.; Sharma, V.R.; Sheikh, I.; Sankhyan, A.; Aggarwal, D.; Sharma, N.K. Anticancer potential of natural products: recent trends, scope and relevance. Lett. Appl. NanoBioScience 2019, 9, 902-907, https://doi.org/10.33263/LIANBS91.902907.

14. Luo, H.; Vong, C.T.; Chen, H.; Gao, Y.; Lyu, P.; Qiu, L.; Zhao, M.; Liu, Q.; Cheng, Z.; Zou, J. Naturally occurring anticancer compounds: shining from Chinese herbal medicine. Chin Med 2019, 14, https://doi.org/10.1186/s13020-019-0270-9.

15. Guerriero, E.; Sorice, A.; Capone, F.; Storti, G.; Colonna, G.; Ciliberto, G.; Costantini, S. Combining doxorubicin with a phenolic extract from flaxseed oil: Evaluation of the effect on two breast cancer cell lines. Int J Oncol 2017, 50, 468-476, https://doi.org/10.3892/ijo.2017.3835.

16. Fallahian, F.; Aghaei, M.; Abdolmohammadi, M.H.; Hamzeloo-Moghadam, M. Molecular mechanism of apoptosis induction by Gaillardin, a sesquiterpene lactone, in breast cancer cell lines : Gaillardin-induced apoptosis in breast cancer cell lines. Cell Biol Toxicol 2015, 31, 295-305, https://doi.org/10.1007/s10565016-9312-6.

17. Gach, K.; Dlugosz, A.; Janecka, A. The role of oxidative stress in anticancer activity of sesquiterpene lactones. Naunyn Schmiedebergs Arch Pharmacol 2015, 388, 477-86, https://doi.org/10.1007/s00210-0151096-3.

18. Khomarlou, N.; Aberoomand-Azar, P.; Lashgari, A.P.; Tebyanian, H.; Hakakian, A.; Ranjbar, R.; Ayatollahi, S.A. Essential oil composition and in vitro antibacterial activity of Chenopodium album subsp. striatum. Acta Biol Hung 2018, 69, 144-155, https://doi.org/10.1556/018.69.2018.2.4.

19. Taherian, A.; Fazilati, M.; Moghadam, A.T.; Tebyanian, H. Optimization of purification procedure for horse F(ab')2 antivenom against Androctonus crassicauda (Scorpion) venom. Trop J Pharm Res 2018, 17, 409414, https://doi.org/10.4314/tjpr.v17i3.4.

20. Atarod, M.; Safari, J.; Tebyanian, H. Ultrasound irradiation and green synthesized CuO-NiO-ZnO mixed metal oxide: An efficient sono/nano-catalytic system toward a regioselective synthesis of 1-aryl-5-amino1H-tetrazoles. Synth. Commun 2020, 1-14, https://doi.org/10.1080/00397911.2020.1761396.

21. Seifi Kafshgari, H.; Yazdanian, M.; Ranjbar, R.; Tahmasebi, E.; Mirsaeed, S.; Tebyanian, H.; Ebrahimzadeh, M.A.; Goli, H.R. The effect of Citrullus colocynthis extracts on Streptococcus mutans, Candida albicans, normal gingival fibroblast and breast cancer cells. $J$ Biol Res 2019, 92, 8201 https://doi.org/10.4081/jbr.2019.8201. 
22. Daneshparvar, H.; Sadat-Shirazi, M.S.; Fekri, M.; Khalifeh, S.; Ziaie, A.; Esfahanizadeh, N.; Vousooghi, N.; Zarrindast, M.R. NMDA receptor subunits change in the prefrontal cortex of pure-opioid and multi-drug abusers: a post-mortem study. Eur Arch Psychiatry Clin Neurosci 2019, 269, 309-315, https://doi.org/10.1007/s00406-018-0900-8.

23. Babavalian, H.; Latifi, A.M.; Shokrgozar, M.A.; Bonakdar, S.; Tebyanian, H.; Shakeri, F. Cloning and expression of recombinant human platelet-derived growth factor-BB in Pichia Pink. Cell Mol Biol (Noisyle-grand) 2016, 62, 45-51, https://doi.org/10.14715/cmb/2016.62.8.8.

24. Tebyanian, H.; Mirhosseiny, S.H.; Kheirkhah, B.; Hassanshahian, M.; Farhadian, H. Isolation and Identification of Mycoplasma synoviae From Suspected Ostriches by Polymerase Chain Reaction, in Kerman Province, Iran. Jundishapur J Microbiol 2014, 7, e19262, https://doi.org/10.5812/jjm.19262.

25. Heidari, M.F.; Arab, S.S.; Noroozi-Aghideh, A.; Tebyanian, H.; Latifi, A.M. Evaluation of the substitutions in 212, 342 and 215 amino acid positions in binding site of organophosphorus acid anhydrolase using the molecular docking and laboratory analysis. Bratisl Lek Listy 2019, 120, 139-143, https://doi.org/10.4149/BLL_2019_022.

26. Rezaeeyan, Z.; Safarpour, A.; Amoozegar, M.A.; Babavalian, H.; Tebyanian, H.; Shakeri, F. High carotenoid production by a halotolerant bacterium, Kocuria sp. strain QWT-12 and anticancer activity of its carotenoid. EXCLI J 2017, 16, 840-851, https://doi.org/10.17179/excli2017-218.

27. Zolfaghar, M.; Amoozegar, M.A.; Khajeh, K.; Babavalian, H.; Tebyanian, H. Isolation and screening of extracellular anticancer enzymes from halophilic and halotolerant bacteria from different saline environments in Iran. Mol. Biol. Rep 2019, 46, 3275-3286, https://doi.org/10.1007/s11033-019-04787-7.

28. Xu, L.; Grandi, N.; Del Vecchio, C.; Mandas, D.; Corona, A.; Piano, D.; Esposito, F.; Parolin, C.; Tramontano, E. From the traditional Chinese medicine plant Schisandra chinensis new scaffolds effective on HIV-1 reverse transcriptase resistant to non-nucleoside inhibitors. J Microbiol 2015, 53, 288-93, https://doi.org/10.1007/s12275-015-4652-0.

29. Ren, Y.; Yu, J.; Kinghorn, A.D. Development of Anticancer Agents from Plant-Derived Sesquiterpene Lactones. Curr Med Chem 2016, 23, 2397-420, https://doi.org/10.2174/0929867323666160510123255.

30. Fadayomi, I.E.; Forsyth, N.; Li, W.-W. P31 Role of sesquiterpene lactones against human ovarian cancer. Biochemical Pharmacology 2017, 139, 134-135, https://doi.org/10.1016/j.bcp.2017.06.032.

31. Abdelaziz, H.M.; Elzoghby, A.O.; Helmy, M.W.; Samaha, M.W.; Fang, J.Y.; Freag, M.S. Liquid crystalline assembly for potential combinatorial chemo-herbal drug delivery to lung cancer cells. Int J Nanomedicine 2019, 14, 499-517, https://doi.org/10.2147/IJN.S188335.

32. Bourhia, M.; Abdelaziz Shahat, A.; Mohammed Almarfadi, O.; Ali Naser, F.; Mustafa Abdelmageed, W.; Ait Haj Said, A.; El Gueddari, F.; Naamane, A.; Benbacer, L.; Khlil, N. Ethnopharmacological survey of herbal remedies used for the treatment of cancer in the greater Casablanca-Morocco. Evid Based Complement Alternat Med 2019, 2019, https://doi.org/10.1155/2019/1613457.

33. Leverson, J.D.; Phillips, D.C.; Mitten, M.J.; Boghaert, E.R.; Diaz, D.; Tahir, S.K.; Belmont, L.D.; Nimmer, P.; Xiao, Y.; Ma, X.M.; Lowes, K.N.; Kovar, P.; Chen, J.; Jin, S.; Smith, M.; Xue, J.; Zhang, H.; Oleksijew, A.; Magoc, T.J.; Vaidya, K.S.; Albert, D.H.; Tarrant, J.M.; La, N.; Wang, L.; Tao, Z.F.; Wendt, M.D.; Sampath, D.; Rosenberg, S.H.; Tse, C.; Huang, D.C.; Fairbrother, W.J.; Elmore, S.W.; Souers, A.J. Exploiting selective BCL-2 family inhibitors to dissect cell survival dependencies and define improved strategies for cancer therapy. Sci Transl Med 2015, 7, 279ra40, https://doi.org/10.1126/scitranslmed.aaa4642.

34. Ding, A.X.; Sun, G.; Argaw, Y.G.; Wong, J.O.; Easwaran, S.; Montell, D.J. CasExpress reveals widespread and diverse patterns of cell survival of caspase-3 activation during development in vivo. Elife 2016, 5, https://doi.org/10.7554/eLife.10936.

35. Mosaddegh, M.; Taheri, M.; Eslami Tehrani, B. Apoptotic potential of two Caryophyllaceae species in MCF7 and MDA-MB-468 cell lines. RJP 2018, 5, 63-69. 